\title{
Frontières
}

\section{Bibliographie indicative sur les musiques et la mort}

\section{Joseph J. Lévy}

Volume 20, numéro 2, printemps 2008

Les musiques et la mort

URI : https://id.erudit.org/iderudit/018368ar

DOI : https://doi.org/10.7202/018368ar

Aller au sommaire du numéro

Éditeur(s)

Université du Québec à Montréal

ISSN

1180-3479 (imprimé)

1916-0976 (numérique)

Découvrir la revue

Citer ce document

Lévy, J. J. (2008). Bibliographie indicative sur les musiques et la mort.

Frontières, 20(2), 121-121. https://doi.org/10.7202/018368ar d'utilisation que vous pouvez consulter en ligne.

https://apropos.erudit.org/fr/usagers/politique-dutilisation/ 


\section{BIBLIOGRAPHIE INDICATIVE SUR LES MUSIQUES ET LA MORT}

Joseph J. Lévy

BAGNERIS, V., E. MARSALIS et L. TOUCHET (1998). Rejoice When You Die: New Orleans Jazz Funerals, Everbest Printing Company.

BAKAN, M.B. (2000). Music of Death and New Creation: Experiences in the World of Balinese Gamelan Beleganjur, Chicago, Chicago University Press, coll. "Chicago Studies in Ethnomusicology ".

BRIGHT, R. (2002). Supportive Eclectic Music Therapy for Grief and Loss: A Practical Handbook for Professionals, St. Louis, MMB Music.

CAHIERS DE LITTÉRATURE ORALE (1990). Chanter la mort, $n^{\circ} 27$.

COHN, N. (2005). Triksta: Life and Death and New Orleans Rap, Vintage Books.

CONRAD, P. (1989). A Song of Love and Death: Meaning of Opera, Graywolf Press.

DAVIES, P.J. (2001). Beethoven in Person: His Deafness, Illnesses and Death. Contributions to the Study of Music \& Dance, Westport, Connecticut, Greenwood Press.

DAVIS, S. (2004). Jim Morrison: Life, Death, Legend, New York, Gotham.

DE LA PARRA, F. (2000). Living the Blues: Canned Heat s Story of Music, Drugs, Death, Sex and Survival, Ruf Records.

DE STABENRATH, B. (2006). Dictionnaire des destins brisés du rock, Paris, Scali.

DU CLOSEL, A. (2005). Les voix étouffées du III Reich, Entartete Musik, Paris, Actes Sud.

GAMMON, V. (2008). Desire, Drink and Death in English Folk and Vernacular Song, 1600-1900, Ashagate Publishing Group.

GILBERT, S. (2005). Music in the Holocaust: Confronting Life in the Nazi Ghettos and Camps, Oxford, Oxford University Press.
HALL. T. (1996). They Died Too Young: The Brief Lives and Tragic Deaths of the Mega-Star Legends of Our Time, Parragon Books Ltd.

HOCQUART, J.-V. (1987). Mozart, l'amour, la mort, Paris, Éditions Lattès.

HUTCHEON, L. et M. HUTCHEON (2004). Opera: The Art of Dying, Harvard, Harvard University Press.

HUTCHEON, L., M. HUTCHEON et S.L. GILMAN (1999). Opera: Desire, Disease and Death (Texts \& Contexts), University of Nebraska Press.

JENNINGS, D. (2008). Sing Me Back Home: Love, Death, and Country Music, Faber and Faber.

KATZ, G. (1996). Death by Rock and Roll: Untimely Deaths of the Legends of Rock, New York, Carol Publishing Group.

LEE, C. (1996). Music at the Edge: The Music Therapy Experiences of a Musician with AIDS, Londres et New York, Routledge.

LEVEY, M. (1995). The Life and Death of Mozart, Stein and Day.

MAGOWAN, F. (2007). Melodies of Mourning: Music \& Emotion in Northern Australia, University of Western Australia Press.

MAI, F.M. (2007). Diagnosing Genius: The Life and Death of Beethoven, McGill-Queen's University Press.

MEYER-BAER, K. (1970). Music of the Spheres and the Dance of Death: Studies in Musical Iconology, Princeton, Princeton University Press.

POLLOCK, G.H. (1990). "Mourning and memorialization through music», dans S. FEDER, R. L. KARMEL et G. POLLOCK. (dir.), Psycho-analytic Explorations in Music, New York, International Universities Press, p. 195208.

POLLOCK, G.H. (1971). "On time, death, and immortality ", Psychoanalytic Quarterly, vol. 40, p. $435-446$.

POZNANSKY, A. (1996). Tchaikovsky s Last Days: A Documentary Study, Oxford, Oxford University Press.
QUIGNARD, P. (1996). La haine de la musique, Paris, Gallimard, coll. «Folio».

ROBERTSON, A. (1968). Requiem: Music of Mourning and Consolation, New York, Praeger.

SCHMALHAUSEN, L. et A. WALKER (2002). The Death of Franz Liszt: Based on the Unpublished Diary of His Pupil Lina Schmalhausen, Cornell University Press.

SCHNEIDER, M. (2001). Musiques de nuit, Paris, Éditions Odile Jacob.

SCRUTON, R. (2004). Death-devoted Heart: Sex and the Sacred in Wagner's Tristan and Isolde, Oxford, Oxford University Press.

SEKELES, C. (2007). Music Therapy: Death and Grief, Gilsum, Barcelone, Barcelona Publishers.

SPENCER, F.J. (2002). Jazz and Death, Jackson, University Press of Mississippi.

STAFFORD, W. (1991). Mozart s Death: A Corrective Survey of the Legends Surrounding His Death, Londres, Macmillan.

STEIN, A. (2004a). « Music, Mourning, and Consolation ", Journal of the American Psychoanalytic Association, vol. 52, p. 783-811.

STEIN, A. (2004b). «Music and trauma in Polanski s The Pianist ", International Journal of Psychoanalysis, vol. 85, p. 755-765.

THOMPSON, D. (1999). Better to Burn Out: The Cult of Death in Rock'n Roll, New York, Thunder's Mouth Press.

THURMAN, H. (2004). Deep River and the Negro Spiritual Speaks of Life and Death, Richmond, Friends United Press.

WILENZ, S. et G. MARCUS (2005). The Rose and the Briar: Death, Love and Liberty in the American Ballad, New York, W. W. Norton.

WORTHEN, J. (2007). Robert Schumann: Life and Death of a Musician, Yale University Press.

ZALUSKI, I. et P. ZALUSKI (2003). Deaths of the Great Composers, Blackie \& Co Publishers.

\title{
APPEL D'ARTICLES
}

\author{
Sur les thèmes suivants : \\ LE SUICIDE \\ LE MAL-ÊTRE ET LES ANTIDÉPRESSEURS
}

Avant de soumettre votre article, veuillez consulter les Normes de présentation des manuscrits des Presses de l'Université du Québec disponibles à l'adresse $<$ www.puq.ca/fr/download/normes.pdf>

Faites-nous-le ensuite parvenir à: frontières@uqam.ca

Les articles soumis seront évalués par un comité scientifique externe. 